\title{
Konseling Kognitif dengan Teknik Role Model Ki Barak Panji Sakti dan Malin Kundang Untuk Mengembangkan Minat Computational
}

\author{
Luh Pratamawati ${ }^{1}$, I Ketut Dharsana ${ }^{2}$ \\ Universitas Pendidikan Ganesha \\ e-mail: iketut.dharsana@undiksha.ac.id
}

Received March 01, 2018; Revised April 01, 2018; Accepted Mei 01, 2018; Published Online June, 302018

\section{Conflict of Interest Disclosures:}

The authors declare that they have no significant competing financial, professional or personal interests that might have influenced the performance or presentation of the work described in this manuscript.

\begin{abstract}
Penelitian ini bertujuan untuk menganalisis efektivitas konseling kognitif (Aaron Beck) dengan teknik ki barak panji sakti dan teknik malin kundang terhadap peningkatan minat computational. Sampel penelitian ini adalah 52 siswa yang dilakukan dengan menggunakan teknik purposive sampling. Teknik analisis yang digunakan adalah anava dua jalur dengan desain 2x2 faktorial dan t-scheffe. Hasil penelitian menunjukkan bahwa: (1) terdapat perbedaan konseling kognitif (Aaron Beck) antara siswa yang mengikuti teknik ki barak panji sakti dengan teknik malin kundang terhadap minat computational $(\mathrm{F}=6,210 ; \mathrm{p}<0,05)$, (2) terdapat pengaruh interaksi konseling kognitif (Aaron Beck) teknik ki barak panji sakti dengan teknik malin kundang terhadap minat computational $(\mathrm{F}=15,642 ; \mathrm{p}<0,05)$, (3) terdapat perbedaan minat computational pada siswa yang mendapat teknik ki barak panji sakti dibandingkan dengan teknik malin kundang $(\mathrm{t}=9,559$; $\alpha<2,008)$.
\end{abstract}

Keywords: konseling kognitif, teknik role model ki barak panji sakti, malin kundang, minat computational

How to Cite: Pratamawati, L., \& Dharsana, I. K. 2018. Konseling Kognitif dengan Teknik Role Model Ki Barak Panji Sakti dan Malin Kundang Untuk Mengembangkan Minat Computational. Bisma, 2 (1): pp. 10-21, DOI: 10.24036/XXXXXXXXXX-X 


\section{Pendahuluan}

Pengamatan yang dilakukan terhadap siswa di kelas VII-1 SMP Negeri 2 Singaraja, secara khusus peneliti mengamati gejala perilaku siswa terkait minat computational, seperti siswa terlihat mampu mengikuti kegiatan dan memiliki keinginan dalam bidang hitung menghitung bidang angka, menghitung benda, banyaknya keperluan dan rencana anggaran biaya, matematika, keinginan, aktivitas, kebutuhan, bertindak, dan berpikir yang ditunjukkan kesenangan dalam bidang hitung menghitung.

Disisi lain juga ada siswa yang menunjukkan sikap seperti siswa tidak mau aktif dalam kelas, lebih senang terdiam ketika mendapat berkaitan dengan materi yang berkaitan dengan hitung-menghitung, ketika mendapat pelajaran hitung menghitung sering bermain-main, bercanda dengan temannya saat mendapatkan pelajaran matematika. Berdasarkan gejala perilaku yang ditunjukkan oleh siswa di atas, maka dapat dikatakan bahwa siswa tersebut perlu memenuhi minat hitung-menghitung (minat computational).

Menurut Dharsana (2014:1001) "Minat computational adalah minat untuk bekerja dalam bidang hitung menghitung bidang angka, menghitung benda, banyaknya keperluan dan rencana anggaran biaya, matematika, akutansi dan perbankan. Berdasarkan definisi tersebut, maka "minat computational" dalam hal ini mengandung 3 aspek yaitu: (1) Kemampuan seseorang hitung menghitung bidang angka, (2) Kemampuan seseorang hitung menghitung bidang benda (3) Kemampuan seseorang hitung menghitung banyaknya keperluan dan rencana anggaran biaya.

Dalam penelitian ini yang dimaksud dengan "minat computational" adalah Minat computational adalah minat untuk bekerja dalam bidang hitung menghitung bidang angka, menghitung benda, banyaknya keperluan dan rencana anggaran biaya, matematika, akutansi dan perbankan. Berdasarkan definisi tersebut maka Minat Computational dalam hal ini mengandung mengandung indikator yaitu: (1) Kemampuan seseorang hitung menghitung bidang angka, (2) Kemampuan seseorang hitung menghitung bidang benda (3) Kemampuan seseorang hitung menghitung banyaknya keperluan dan rencana anggaran biaya.

Kemampuan seseorang hitung menghitung bidang angka adalah minat yang dimiliki oleh seseorang untuk menghitung bidang angka dengan maksud untuk melakukan dan berlatih dalam menghitung angka, seperti dalam pelajaran matematika.

Kemampuan seseorang hitung menghitung bidang benda adalah minat yang dimiliki oleh seseorang untuk memperoleh daya tarik untuk menghitung benda yang ada di sekitarnya sesuai dengan keinginanya.

Kemampuan seseorang hitung menghitung banyaknya keperluan dan rencana anggaran biaya yaitu minat seseorang bekerja dalam bidang membuat rencana anggaran biaya. 
Upaya yang dapat dilakukan dalam rangka memenuhi minat hitung-menghitung (minat computational) siswa adalah melalui inovasi dalam proses pembelajaran, upaya pelatihan melalui kegiatan ekstrakurikuler, serta dengan treatmen psikologi atau layanan bimbingan konseling, dan training. Namun jika dilihat dari latar belakang peneliti sebagai calon guru Bimbingan Konseling maka upaya yang cocok diberikan yaitu melalui proses bimbingan dan konseling. Bimbingan ini diberikan dengan mengoptimalisasikan pemberian layanan bimbingan konseling kepada siswa.

Gejala "minat computational" tersebut diatas, dapat diinterpretasikan dengan teori konseling. Menurut Dharsana (2010:2), model teori-teori konseling yaitu "Teori Psikoanalitik Sigmund Freud; Teori Konseling Self Adler; Teori Konseling Kelompok Psikodinamika dalam Teori Asumsi Melanie Klein; Teori Konseling yang Berpusat pada Pribadi oleh Calr Roger; Teori Konseling Gestalt Fritz Perls; Teori Analisis Transaksional Eric Berne; TeorI Reality Counselling (William Glasser); Teori Motivasi Manusia "Maslow's"; Teori Logo Konseling Victor Frakl; Teori Konseling Kognitif (Aaron Beck); Teori Melatih Konseling Tingkah Laku (Oleh Krumboltz); Teori Behavioral (Teori Tingkah laku); Teori Kognitif Sosial (Albert Bandura); Teori Rasional Emotive Behavioral Counselling Alberrt Ellis; Teori Konsepsi George Kelly; Teori Eklecticism; Teori Personologi Murray; Teori Pemilihan Jabatan John L.Holland; Teori Perkembangan Karir dan Perkembangan Hidup (Super); Teori Pemilihan Jabatan atau Karir menurut Anne Roe; Teori Perkembangan Karir oleh Ginzberg dan Konseling Karir Trait dan Faktor". Berdasarkan hal tersebut, maka dalam penelitian ini teori konseling yang digunakan adalah teori konseling Kognitif Behavioral.

Konseling Kognitif Behavioral dipelopori oleh Aaron T. Beck. Pendekatan kognitif berfokus pada pikiran, asumsi dan kepercayaan dengan memfasilitasi individu untuk belajar mengenali dan mengubah kesalahan yang berkaitan dengan positive thinking (berpikir positif) dan happy thinking (berpikir bahagia). Sedangkan pendekatan tingkah laku membantu untuk membentuk sebuah hubungan positif antara situasi permasalahan dengan kebiasaan merespon suatu permasalahan. Hal ini bertumpu pada proses belajar menenangkan pikiran dengan dukungan pengubahan tingkah laku untuk lebih baik sehingga nantinya mampu membentuk pola pikir yang jelas dan mampu memutuskan suatu hal dengan baik.

Pendekatan model dengan Konseling Kognitif (Aaron Beck) dalam penelitian ini adalah proses untuk meningkatkan minat computational dengan skill konseling sesuai prosedur dan langkah-langkah yang telah ditentukan melalui bimbingan klasikal, bimbingan kelompok, konseling kelompok dan konseling individual.

Tujuan dari konseling kognitif(Aaron Beck) ini yaitu untuk membantu konseli menyelesaikan permasalahan masa kini namun tidak melupakan masa lalunya dengan mengubah pemikiran irasional menjadi rasional sehingga nantinya dapat berpengaruh pada pengambilan tindakan yang negatif menjadi positif dengan menyelaraskan berpikir, merasa dan bertindak. Selain itu fokus konseling dalam teori ini yaitu pada Aspek kognitif dalam konseling kognitif memfokuskan konseling dalam mengubah cara berpikir, kepercayaan, sikap, asumsi, imajinasi dan memfasilitasi konseli belajar mengenali dan mengubah kesalahan dalam aspek kognitif. Sedangkan aspek behavioral dalam konseling kognitif behavioral memfokuskan konseling pada proses belajar mengubah perilaku, menenangkan pikiran dan tubuh sehingga merasa lebih baik, berpikir lebih jelas dan membantu membuat keputusan yang tepat. 
Berdasarkan konsep tersebut diatas maka prosedur pelaksanaan model Konseling Kognitif (Aaron Beck) dalam penelitian ini dilaksanakan sebagai berikut: 1) Mengobservasi gejala "minat computational", 2) Mentabulasi gejala "minat computational", 3) Menganalisis gejala "minat computational", 4) Mengidentifikasi gejala "minat computational", 5) Melakukan diagnosa, 6) Melakukan prognosa, 7) Melakukan tindakan/ treatment, 8) Evaluasi.

Gejala "minat computational" diatas, akan dapat meningkat manakala disentuh dan di treatment dengan cara atau teknik yang selaras dengan teori konseling. Model Konseling Kognitif (Aaron Beck) memiliki teknik-teknik konseling sebagai berikut: 1) desensitisasi sistematis, 2) teknik relaksasi, 3) teknik flooding, 4) reinforcement technique, 5) modelling, 6) cognitive restructuring, 7) assertive training, 8) self management, 9) role playing, 10) terapi aversi, dan 11) self-instruction. Berdasarkan teknik-teknik konseling yang ada maka peneliti menetapkan teknik modeling dalam Teknik Ki Barak Panji Sakti dan Teknik Malin Kundang sebagai strategi yang digunakan untuk meningkatkan "minat computational" siswa.

Menginstruksi diri (minat computational) pada hakikatnya adalah bentuk dari menstrukturisasi kembali aspek kognitif. Teknik Ki Barak Panji Sakti adalah salah satu teknik local genius yang diangkat dari salah satu cerita rakyat dengan judul Anglurah Ki Barak Panji Sakti dimana cerita Malin Kundang menceritakan Raja Anglurah Ki Barak Panji Sakti adalah pendiri kerajaan Den Bukit yang memerintah pada tahun 16601699.

Sehingga, diketahui bahwa teknik ki barak panji sakti adalah cara untuk meningkatkan minat computational membantu individu untuk mampu menginstruksi diri melalui skill konseling, prosedur, dan langkah-langkah dengan menggunakan bimbingan klasikal, bimbingan kelompok, konseling kelompok dan konseling individual yang sudah ditentukan.

Menurut Dharsana (2015), teknik Ki Barak Panji Sakti memiliki prosedur yaitu 1) merencanakan lembaran "minat computational", 2) menyebarkan lembar kuesioner minat computational", 3) menganalisis hasil kuesioner "minat computational", 4) melakukan treatment dengan menggunakan Teknik Ki Barak Panji Sakti. Teknik Ki Barak Panji Sakti mengandung langkah-langkah sebagai berikut: 1) Membentuk peranperan terkait Minat Computational, 2) Melatih peran-peran dalam minat computational, 3) Menyajikan hasil olah data dalam bentuk drama 4) Menyaksikan Ki Barak Panji Sakti 5) Merefleksikan tampilan

peneliti juga menyandingkan Teknik Malin Kundang untuk mendukung penelitian terhadap peningkatan minat computational pada diri siswa. Teknik Malin Kundang adalah salah satu teknik local genius yang diangkat dari salah satu cerita rakyat dengan judul Malin Kundang, dimana cerita Malin Kundang menceritakan seorang anak yang durhaka terhadap orang tuanya.

Sehingga diketahui bahwa teknik Malin Kundang adalah cara untuk meningkatkan minat computational membantu individu untuk mampu mengelola diri melalui skill konseling, prosedur, dan langkah-langkah dengan menggunakan bimbingan klasikal, bimbingan kelompok, konseling kelompok dan konseling individual yang sudah ditentukan. 
Menurut Dharsana (2015), teknik Ki Barak Panji Sakti memiliki prosedur yaitu 1) merencanakan lembaran "minat computational", 2) menyebarkan lembar kuesioner "minat computational", 3) menganalisis hasil kuesioner "minat computational", 4) melakukan treatment dengan menggunakan Teknik Malin Kundang. Teknik Malin Kundang mengandung langkah-langkah sebagai berikut: 1) Membentuk peran-peran terkait minat computational, 2) Melatih peran-peran dalam minat computational, 3) Menyajikan hasil olah data dalam bentuk drama 4) Menyaksikan Malin Kundang 5) Merefleksikan tampilan

Pemberian teknik Ki Barak Panji Sakti dan teknik Malin Kundang ini dilakukan untuk membandingkan dan melihat sejauh mana keefektifan strategi yang peneliti berikan dalam meningkatkan "minat computational siswa.

Berdasarkan pemaparan, pemikiran, serta fakta yang terjadi di lapangan, peneliti mengangkat tema tentang "minat computational" yang akan ditingkatkan menggunakan teknik Ki Barak Panji Sakti dan teknik Malin Kundang dalam model Konseling Kognitif Behavioral (Aaron Beck). Kedua teknik atau strategi ini akan diuji keefektivitasannya dalam meningkatkan "minat computational" siswa. Dalam hal ini, peneliti akan melakukan treatment terhadap beberapa siswa di kelas VII-1 SMP Negeri 2 Singaraja yang dikategorikan memiliki "minat computational" sedang dan rendah.

Adapun tujuan dari dilaksanakannya penelitian ini yaitu:1) Untuk mengetahui perbedaan konseling kognitif (Aaron Beck)antara siswa yang mengikuti teknik Ki Barak Panji Sakti dengan teknik Malin Kundang terhadap minat computational; 2) Untuk mengetahui pengaruh interaksi konseling kognitif (Aaron Beck) strategi teknik Ki Barak Panji Sakti dan teknik Malin Kundang terhadap minat computational siswa kelas VII-1 SMP Negeri 2 Singaraja; 3) Untuk mengetahui perbedaan minat computational pada siswa yang mendapat treatment teknik Ki Barak Panji Sakti dibandingkan dengan treatment teknik Malin Kundang.

\section{Metode}

Penelitian ini merupakan penelitian eksperimen. Rancangan yang digunakan adalah analisis two faktor design atau faktorial 2x2 (2 level variabel eksperimen dan 2 level variabel atribut). Populasi target dalam penelitian ini adalah seluruh siswa Kelas X SMA Negeri 2 Singaraja tahun pelajaran 2015/2016. Sedangkan pengambilan sampel dalam penelitian ini dilakukan dengan teknik purposive sampling. Peneliti akan mengambil sampel individu sebanyak 60 orang yang, yaitu 30 orang siswa dengan pola asuh acceptenace dan 30 siswa dengan pola asuh rejection. Kemudian membaginya menjadi 2 kelompok yaitu untuk kelompok yang diberikan teknik Self Management Model Yates dan Model Cormier and Cormier. Data pada penelitian ini dikumpulkan menggunakan kuesioner Self Autonomy yang terdiri dari 40 butir soal. Hasil analisis data pada uji coba instrument memberikan harga Alpha Cronbath sebesar 0.939. sesuai kriteria yang telah ditentukan, reliabilitas kuesioner Self Autonomy berada pada kategori sangat tinggi. Dengan demikian kuesioner Self Autonomy yang diuji cobakan memenuhi kriteria untuk digunakan dalam penelitian ini. Analisis data yang digunakan terdiri dari empat bagian, yaitu: (1) analisis deskripsi data, (2) uji prasayarat terdiri dari, uji normalitas sebaran data, uji homogenitas, (3) Uji hipotesis menggunakan Analisis Anava Dua Jalur (ANAVA AB), dan selanjutnya melakukan (4) Uji lanjut menggunakan t-scheffe. 


\section{Hasil Dan Pembahasan}

Sebelum melakukan uji hipotesis terlebih dahulu dilakukan uji prasyarat analis. Hasil uji normalitas menunjukkan bahwa Chi-Kuadrat X2 menunjukkan bahwa seluruh kelompok memiliki harga X2 hitung lebih kecil daripada X2 tabel. Ini berarti H0 diterima (gagal ditolak), maka dua kelompok data berdistribusi normal. Hasil uji homogenitas menunjukkan bahwa menggunakan Levene's Test of Equality of Error Variance menunjukkan bahwa taraf signifikansi lebih besar dari 0.05 , maka varians setiap sampel sama (homogen), jika signifikansi diperoleh lebih kecil dari 0.05, maka varians setiap sampel tidak sama (tidak homogen). Berdasarkan hasil analisis data telah terbukti bahwa terdapat efektifitas konseling behavioral Teknik Self Management Model Yates dan teknik Self Management Model Cormier terhadap Self Autonomy ditinjau dari pola asuh orang tua. Hal ini ditunjukkan dengan hasil sebagai berikut, (1) Terdapat Perbedaan Self Autonomy Antara Siswa Yang Mengikuti Teori Konseling Behavioral Teknik Self Management Model Yates Dengan Siswa Yang Mengikuti Teori Konseling Behavioral Teknik Self Managament Model Cormier $(\mathrm{F}=6,624 ; \mathrm{p}<0.05)$, maka H0 yang menyatakan tidak terdapat perbedaan Self Autonomy antara kelompok siswa yang mengikuti konseling behavioral teknik Self Management Model Yates dengan siswa yang mengikuti konseling behavioral teknik Self Managament Model Cormier ditolak, sebaliknya H1 diterima. Jadi simpulannya bahwa terdapat perbedaan Self Outonomy antara siswa yang mengikuti teori konseling behavioral teknik Self Management Model Yates dengan siswa yang mengikuti teori konseling behavioral teknik Self Management Model Cormier. Rata-rata Self Outonomy kelompok siswa yang mengikuti teori konseling behavioral Self Management Model Cormier $\quad(=151,97)$ lebih rendah daripada siswa yang mengikuti teori konseling behavioral teknik Self Management Model Yates ( =168,37), (2) Terdapat Perbedaan Self Autonomy Antara Siswa Yang Diasuh Dengan Pola Asuh Acceptance Dan yang Diasuh dengan Pola Asuh Rejection ( $F=11,71 ; p<0.05)$, maka H0 yang menyatakan "tidak terdapat perbedaan Self Outonomy antara siswa yang memiliki pola asuh acceptance dengan siswa yang memiliki pola asuh rejection", ditolak, sebaliknya H1 diterima. Jadi simpulannya bahwa terdapat perbedaan Self Outonomy antara siswa yang memiliki pola asuh acceptance dengan siswa yang memiliki pola asuh rejection. Rata-rata self Outonomy kelompok siswa yang memiliki pola asuh aceptance $(=$ 161,23), dan rata-rata Self Outonomy kelompok siswa yang memiliki pola asuh rejection $(=144,57)$. Dari rata-rata tersebut, rata-rata Self Outonomy kelompok siswa yang memiliki pola asuh acceptance lebih tinggi dari kelompok siswa yang memiliki pola asuh rejection. (3) Terdapat pengaruh interaksi antara konseling behavioral dan pola asuh orang tua terhadap Self Autonomy $(\mathrm{F}=17,98 ; \mathrm{p}<0.05)$ maka H0 yang menyatakan tidak terdapat pengaruh interaksi antara teori konseling behavioral dan pola asuh orang tua terhadap Self Outonomy siswa", ditolak, sebaliknya H1 diterima. terdapat pengaruh interaksi antara teori konseling behavioral dan pola asuh orang tua terhadap Self Outonomy", diterima. Jadi, simpulannya adalah terdapat pengaruh interaksi antara teori konseling behavioral dan pola asuh orang tua terhadap Self Outonomy, (4) Terdapat Perbedaan Self Autonomy Antara Siswa Yang Diasuh dengan Pola Asuh Acceptance Dengan Siswa Yang Diasuh Dengan Pola Asuh Rejection Setelah Mengikuti Teori Konseling Behavioral Teknik Self Management Model Yates ( $\mathrm{t}=5.008 ; \alpha<2.048)$ maka H0 yang menyatakan "Tidak terdapat perbedaan self outonomy antara siswa yang diasuh dengan pola asuh acceptance dengan siswa yang diasuh dengan pola asuh rejection setelah mengikuti teori konseling behavioral teknik Self Management Model Yates", ditolak, sebaliknya H1 diterima. Jadi simpulannya bahwa Terdapat perbedaan Self autonomy antara siswa yang diasuh dengan pola asuh acceptance dengan siswa yang diasuh dengan pola asuh rejection setelah mengikuti teori konseling behavioral teknik Self Management Model Yates”, diterima. Simpulan yang dapat ditarik menyatakan bahwa terdapat perbedaan Self autonomy antara siswa yang diasuh dengan pola asuh acceptance dengan siswa yang diasuh dengan pola asuh rejection setelah mengikuti teori konseling behavioral teknik Self Management Model Yates. Secara deskriptif rata-rata Self autonomy kelompok siswa yang diasuh dengan pola asuh acceptance yang mengikuti teori konseling behavioral teknik Self Management Model Yates (=180.400) lebih tinggi dari pada kelompok siswa yang diasuh dengan pola asuh 
rejection yang mengikuti layanan konseling behavioral teknik Self Management Model Yates ( =161.862), (5) Terdapat Perbedaan Self Autonomy Antara Siswa Yang Diasuh dengan Pola Asuh Acceptance Dengan Siswa Yang Diasuh dengan Pola Asuh Rejection Setelah Mengikuti Teori Konseling Behavioral Teknik Self Management Model Cormier ( $\mathrm{t}=7.008 ; \alpha<2.048)$ maka H0 yang menyatakan "Tidak terdapat perbedaan Self autonomy antara siswa yang diasuh dengan pola asuh acceptance dengan siswa yang diasuh dengan pola asuh rejection setelah mengikuti teori konseling behavioral teknik Self Management Model Cormier", ditolak,sedangkan H1 diterima. Jadi simpulananya bahwa simpulan yang dapat ditarik menyatakan terdapat perbedaan Self autonomy antara siswa yang diasuh dengan pola asuh acceptance dengan siswa yang asuh dengan pola asuh rejection setelah mengikuti teori konseling behavioral teknik Self Management Model Cormier. Secara deskriptif rata-rata Self autonomy kelompok siswa yang diasuh dengan pola asuh acceptance yang mengikuti teori konseling behavioral teknik Self Management Model Cormier ( =164.200) lebih besar daripada kelompok siswa yang diasuh dengan pola asuh acceptance yang mengikuti teori konseling behavioral teknik Self Management Model Cormier ( =138.267), (6) Terdapat Perbedaan Self Autonomy Antara Siswa Yang Diasuh dengan Pola Asuh Acceptance Yang Mengikuti Teori Konseling Behavioral Teknik Self Management Model Cormier Dengan Yang Mengikuti Teori Konseling Behavioral Self Management Model Cormier ( $\mathrm{t}=3.861 ; \alpha<2.048)$ maka H0 yang menyatakan Tidak terdapat perbedaan Need of deference antara siswa Perbedaan Self Autonomy Antara Siswa Yang Diasuh dengan Pola Asuh Acceptance Yang Mengikuti Teori Konseling Behavioral Teknik Self Management Model Cormier Dengan Yang Mengikuti Teori Konseling Behavioral Self Management Model Cormier ditolak, sebaliknya H1 diterima. Jadi simpulannya bahwa terdapat perbedaan terdapat perbedaan Self autonomy antara siswa diasuh dengan pola asuh acceeptance yang mengikuti teori konseling behavioral teknik Self Managament Model Yates dengan yang mengikuti teori konseling behavioral teknik Self Management Model Cormier. Secara deskriptif rata-rata Self autonomy kelompok siswa yang diasuh dengan pola asuh acceptance yang mengikuti teori konseling behavioral teknik Self Management Model Yates ( $=180.400)$ lebih besar daripada kelompok siswa yang diasuh dengan pola asuh acceptance yang mengikuti teori konseling behavioral teknik Self Management Model Cormier (=164.200). (7) Terdapat Perbedaan Self Autonomy Antara Siswa Yang Diasuh dengan Pola Asuh Rejection Yang Mengikuti Teori Konseling Behavioral Teknik Self Managamant Model Yates Dengan Yang Mengikuti Teori Konseling Behavioral Teknik Self Management Model Cormier $(\mathrm{t}=2.252 ; \alpha<2.048)$ maka H0 yang menyatakan bahwa Tidak terdapat Perbedaan Self Autonomy Antara Siswa Yang Diasuh dengan Pola Asuh Rejection Yang Mengikuti Teori Konseling Behavioral Teknik Self Managamant Model Yates Dengan Yang Mengikuti Teori Konseling Behavioral Teknik Self Management Model Cormier ditolak, sebaliknya H1 diterima. Jadi simpulannya bahwa terdapat perbedaan Self autonomy antara siswa yang diasuh dengan pola asuh rejection yang mengikuti teori konseling behavioral teknik Self Management Model Yates dengan yang mengikuti teori konseling behavioral teknik Self Management Model Cormier. Secara deskriptif rata-rata Need of autonomy kelompok siswa yang diasuh dengan pola asuh rejection yang mengikuti teori konseling behavioral teknik Self Management Model Yates $(=161.867)$ lebih besar daripada kelompok siswa yang diasuh dengan pola asuh rejection yang mengikuti teori konseling behavioral teknik Self Managament Model Cormier ( = 138.267).

Konseling behavioral yang sering disebut sebagai konseling tingkah laku merupakan penerapan beragam teknik dan prosedur yang menerapkan prinsip belajar pada pengubahan tingkah laku kearah cara-cara yang lebih adaptif. Dalam penelitian ini, dua teknik yang digunakan untuk memberikan perlakuan terhadap Self autonomy, yaitu teknik Self Managament Model Yates dan teknik Self Managament Model Cormier. Asumsi yang mendasari penggunaan teknik Self Managament Model Yates menyebutkan bahwa "pengelolaan diri adalah suatu strategi yang mendorong individu untuk mampu mengarahkan perilaku perilakunya sendiri dengan tanggung jawab atas tindakannya untuk mencapai kemajuan diri" dalam teknik Self managamenet Model Yates terdapat 4 jenis metode yang dikembangkan dalam strategi pengelolaan diri atau self management yaitu : (a) pantau diri (self monitoring), (b) analisis diri (self analysis), (c) mengubah dii (self change), (d) pemeliharaan dan pertahanan diri (self maintance).Self Managament Model Cormier 
and Cormier merupakan teknik kedua. Asumsi dasar mengunakan teknik ini karna menurut Cormier \& Cormier (dalam Siti Nurzaakiyah, dkk : 13) juga menyatakan bahwa Self management atau pengelolaan diri adalah suatu strategi pengubahan perilaku yang dalam prosesnya konseli mengarahkan perubahan perilakunya sendiri dengan suatu teknik atau kombinasi teknik teurapetik. Cormier and Cormier menyebutkan beberapa strategi dari Self Management yang dapat diterapkan diantaranya (a) Patau diri (self monitoring), (b) Reinforcement yang positif (self-reward), (c) Penguasaan terhadap ransangan (stimulus control). Temuan empiris pada penelitian ini menyatakan bahwa terdapat perbedaan nilai Fhitung diperoleh sebesar 6,642 dan Ftabel sebesar 4,00. Jika dibandingkan nilai Fhitung dengan Ftabel didapatkan bahwa Fhitung $>$ Ftabel dengan taraf signifikansi $(\mathrm{p})<0,05$ maka dapat disimpulkan bahwa hipotesis nol yang menyatakan "tidak terdapat perbedaan Self Outonomy antara kelompok siswa yang mengikuti teori konseling behavioral teknik Self Management Model Yates dengan siswa yang mengikuti teori konseling behavioral teknik Self Management Model Cormier", ditolak. Sebaliknya hipotesis alternatif (H1) yang menyatakan bahwa "terdapat perbedaan Self Outonomy antara siswa yang mengikuti teori konseling behavioral teknik Self Management Model Yates dengan siswa yang mengikuti teori konseling behavioral teknik Self Management Model Cormier", diterima.

Jadi simpulannya bahwa terdapat perbedaan Self Outonomy antara siswa yang mengikuti teori konseling behavioral teknik Self Management Model Yates dengan siswa yang mengikuti teori konseling behavioral teknik Self Management Model Cormier. Rata-rata Self Outonomy kelompok siswa yang mengikuti teori konseling behavioral Self Management Model Cormier $(=151,97)$ lebih rendah daripada siswa yang mengikuti teori konseling behavioral teknik Self Management Model Yates ( $=168,37)$. Salah satu faktor yang memperngaruhi Need of autonomy seseorang adalah pola aasuh orang tua. Setiap orang tua memiliki pola asuh yang berbeda antara anak-anaknya. Pola asuh orang tua mempengaruhi perilaku dan sikap anak saat mereka berada di lingkungan pergaulan mereka. Pendidikan dalam keluarga mempengaruhi karakter masing-masing anak, maka dari itu betapa pentingnya pengasuhan, atau pola asuh dan pendidikan orang tua dalam pembentukan dan pertumbuhan anak. Chabib Thoha (1996:109) mengemukakan bahwa pola asuh orang tua adalah suatu cara yang ditempuh orang tua dalam mendidik anak sebagai perwujudan dari rasa tanggung jawab kepada anak. Peran keluarga menjadi penting untuk mendidik anak baik dalam sudut tinjau agama, tinjau sosial kemasyarakatan maupun tinjau individu. Jika pendidikan keluarga dapat berlangsung dengan baik maka mampu menumbuhkan perkembangan kepribadian anak menjadi manusia yang kuat dan mandiri, potensi jasmani dan rohani serta intektual yang berkembang secara optimal. Sikap dan perilaku anak yang diasuh dengan pola asuh acceptance tentu akan berbeda dengan sikap dan perilaku anak yang diasuh dengan pola asuh rejection. Hal ini tentu saja dipengaruhi oleh cara para orang tua mendidik anakanaknya. Anak yang diasuh dengan pola asuh acceptance akan lebih disayangi oleh kedua orang tuanya, diberikan kebebasan dan kepercayaan, orang tua selalu memantau perilaku anak, mengembangkan hubungan yang hangat dengan anak, sikap anak yang diasuh dengan pola asuh acceptance akan mampu bertanggung jawab, mau bekerjasama, tetapi anak yang disuh dengan pola asuh acceptance kadang kala terlalu dimanjakan sehingga akan bersifat egois. Sedangkan perilaku atau sikap anak yang diasuh dengan pola asuh rejection akan cenderung lebih pendiam, karena kurangnya perhatian dari orang tua, orang tua juga kurang memperdulikan kesejahteraan anak, dan menampilkan sikap permusuhan atau mendominasi anak, denngan pola asuh yang diterapkan orang tua kepada anak seperti itu maka perilaku anak akan mudah marah, tidak patuh, pemalu, dan sulitnya anak untuk bergaul. Setiap orang tua memiliki cara atau pola asuh tersendiri dalam mendidik anak-anaknya, namun setiap pola asuh yang diterapkan memiliki sisi positif maupun sisi negatifnya, itu semua tergantung bagaimana cara anak menyikapi atau menerima pola asuh yang diterapkan oleh orang tuanya.

Temuan empiris penelitian ini menyatakan bahwa terdapat perbedaan Need of autonomy antara siswa yang diaasuh dengan pola asuh acceptance dengan anak yang disuh dengan pola asuh rejection. nilai Fhitung diperoleh sebesar 11,714 dan Ftabel sebesar 4,00. Jika dibandingkan nilai Fhitung dengan Ftabel didapatkan bahwa Fhitung $>$ Ftabel dengan taraf signifikansi $(\mathrm{p})<0,05$ maka dapat disimpulkan bahwa hipotesis nol 
yang menyatakan "tidak terdapat perbedaan Self Outonomy antara siswa yang memiliki pola asuh acceptance dengan siswa yang memiliki pola asuh rejection", ditolak. Sebaliknya hipotesis alternatif (H1) yang menyatakan bahwa "terdapat perbedaan Self Outonomy antara siswa yang memiliki pola asuh acceptance dengan siswa yang memiliki pola asuh rejection", diterima. Jadi simpulannya bahwa terdapat perbedaan Self Outonomy antara siswa yang memiliki pola asuh acceptance dengan siswa yang memiliki pola asuh rejection. Rata-rata self Outonomy kelompok siswa yang memiliki pola asuh aceptance $(=161,23)$, dan rata-rata Self Outonomy kelompok siswa yang memiliki pola asuh rejection $(=144,57)$. Dari rata-rata tersebut, rata-rata Self Outonomy kelompok siswa yang memiliki pola asuh acceptance lebih tinggi dari kelompok siswa yang memiliki pola asuh rejection.

Rancangan analisis varians dua jalur dirancang untuk menampilkan interaction effect antara teori konseling behavioral dan pola asuh orang tua terhadap Need of Autonomy. Interaction effect merupakan pengaruh persilangan antara variabel baris dan variabel kolom yang digunakan. Selanjutnya hasil pengujian interaksi teori konseling behavioral dan pola asuh orang tua terhadap Need of autonomy diperoleh nilai Fhitung diperoleh sebesar 17,98 dan Ftabel sebesar 4,00. Jika dibandingkan nilai Fhitung dengan Ftabel didapatkan bahwa Fhitung $>$ Ftabel dengan taraf signifikansi $(p)<0,05$ maka dapat disimpulkan bahwa hipotesis nol yang menyatakan "tidak terdapat pengaruh interaksi antara teori konseling behavioral dan pola asuh orang tua terhadap Self Outonomy siswa", ditolak. Sebaliknya, hipotesis alternatif (H1) yang menyatakan bahwa "terdapat pengaruh interaksi antara teori konseling behavioral dan pola asuh orang tua terhadap Self Outonomy", diterima. Jadi, simpulannya adalah terdapat pengaruh interaksi antara teori konseling behavioral dan pola asuh orang tua terhadap Self Outonomy

Karena terdapat pengaruh interaksi yang signifikan antara konseling behavioral dan pola asuh orang tua terhadap Self autonomy, maka dilanjutkan dengan pengujian signifikan masing-masing pola asuh orang tua, yaitu pada kelompok siswa yang diasuh dengan pola asuh acceptance dan siswa yang diasuh dengan pola asuh rejection dengan teori konseling behavioral teknik Self Mangemenet Model Yates. Hasil penelitian Berdasarkan hasil perhitungan diatas thitung diperoleh sebesar 5.008 dan $\mathrm{t}(28 ; 0.05)$ sebesar 2.048. Jika dibandingkan nilai thitung dengan $\mathrm{t}(\mathrm{dk} ; \alpha)$ didapatkan bahwa thitung $>\mathrm{t}(\mathrm{dk} ; \alpha)$ maka dapat disimpulkan bahwa hipotesis nol yang menyatakan "Tidak terdapat perbedaan self outonomy antara siswa yang diasuh dengan pola asuh acceptance dengan siswa yang diasuh dengan pola asuh rejection setelah mengikuti teori konseling behavioral teknik Self Management Model Yates", ditolak. Sebaliknya, hipotesis alternatif (H1) yang menyatakan bahwa "Terdapat perbedaan Self autonomy antara siswa yang diasuh dengan pola asuh acceptance dengan siswa yang diasuh dengan pola asuh rejection setelah mengikuti teori konseling behavioral teknik Self Management Model Yates", diterima. Simpulan yang dapat ditarik menyatakan bahwa terdapat perbedaan Self autonomy antara siswa yang diasuh dengan pola asuh accceptance dengan siswa yang diasuh dengan pola asuh rejection setelah mengikuti teori konseling behavioral teknik Self Management Model Yates.

Secara deskriptif rata-rata Self autonomy kelompok siswa yang diasuh dengan pola asuh acceptance yang mengikuti teori konseling behavioral teknik Self Management Model Yates ( $=180.400)$ lebih tinggi dari pada kelompok siswa yang diasuh dengan pola asuh rejection yang mengikuti layanan konseling behavioral teknik Self Management Model Yates ( =161.862). Dengan membandingkan rata-rata Self autonomy kelompok siswa yang diasuh dengan pola asuh acceptance dan kelompok sisw ayang diasuh dengan pola asuh rejection ternayata rata-rata Need of autonomy kelompok siswa yang diasuh dengan pola asuh acceptance yang mengikuti teori konseling behavioral teknik Self management Model Yates lebih tinggi daripada kelompok siswa yang diasuh dengan pola asuh rejection yang mengikuti teori konseling behavioral teknik Self management Model Yates.

Berdasarkan hasil kajian teori konseling behavioral teknik Self Managamant Model Cormier terhadap pola asuh acceptance dan pola asuh rejection, diperoleh thitung diperoleh sebesar 7.008 dan $\mathrm{t}(28 ; 0.05)$ sebesar 
2.048. Jika dibandingkan nilai thitung dengan $\mathrm{t}(\mathrm{dk} ; \alpha)$ didapatkan bahwa thitung $>\mathrm{t}(\mathrm{dk} ; \alpha)$ maka dapat disimpulkan bahwa hipotesis nol yang menyatakan "Tidak terdapat perbedaan Self autonomy antara siswa yang diasuh dengan pola asuh acceptance dengan siswa yang diasuh dengan pola asuh rejection setelah mengikuti teori konseling behavioral teknik Self Management Model Cormier", ditolak. Sebaliknya, hipotesis alternatif $(\mathrm{H} 1)$ yang menyatakan bahwa "Terdapat perbedaan Self autonomy antara siswa yang diasuh dengan pola asuh acceptance dengan siswa yang diasuh dengan pola asuh rejection setelah mengikuti teori konseling behavioral teknik Self Management Model Cormier", diterima.

Ini berarti simpulan yang dapat ditarik menyatakan terdapat perbedaan Self autonomy antara siswa yang diasuh dengan pola asuh acceptance dengan siswa yang asuh dengan pola asuh rejection setelah mengikuti teori konseling behavioral teknik Self Management Model Cormier. Secara deskriptif rata-rata Self autonomy kelompok siswa yang diasuh dengan pola asuh acceptance yang mengikuti teori konseling behavioral teknik Self Management Model Cormier ( $=164.200)$ lebih besar daripada kelompok siswa yang diasuh dengan pola asuh acceptance yang mengikuti teori konseling behavioral teknik Self Management Model Cormier ( =138.267). Berdasarkan kajian diatas, dapat dikatakan bahwa pelaksanaan teori konseling behavioral teknik Self Managament Model Cormier terhadap Self autonomy memiliki perbedaan pengaruh antara anak yang diasuh dengan acceptance maupun anak yang diasuh dengan pola asuh rejection. Hasil penelitian ini menunjukkan diperoleh sebesar 3.861 dan $\mathrm{t}(28 ; 0.05)$ sebesar 2.048. Jika dibandingkan nilai Fhitung diperoleh sebesar 3.861 dan $\mathrm{t}(28 ; 0.05)$ sebesar 2.048. Jika dibandingkan nilai thitung dengan $\mathrm{t}(\mathrm{dk} ; \alpha)$ didapatkan bahwa thitung $<\mathrm{t}(\mathrm{dk} ; \alpha)$ maka dapat disimpulkan bahwa hipotesis nol yang menyatakan "Tidak terdapat perbedaan Self autonomy antara siswa yang diasuh dengan pola asuh acceptance yang mengikuti teori konseling behavioral teknik Self Management Model Yates dengan yang mengikuti teori konseling behavioral teknik Self Management Model Cormier", ditolak. Sebaliknya, hipotesis alternatif (H1) yang menyatakan bahwa "Terdapat perbedaan Self autonomy antara siswa yang diasuh dengan pola asuh acceptance yang mengikuti teori konseling behavioral teknik Self Management Model Yates dengan yang mengikuti teori konseling behavioral teknik Self Management Model Cormier" diterima.

Simpulan yang dapat ditarik menyatakan bahwa terdapat perbedaan Self autonomy antara siswa diasuh dengan pola asuh acceeptance yang mengikuti teori konseling behavioral teknik Self Managament Model Yates dengan yang mengikuti teori konseling behavioral teknik Self Management Model Cormier Secara deskriptif rata-rata Self autonomy kelompok siswa yang diasuh dengan pola asuh acceptance yang mengikuti teori konseling behavioral teknik Self Management Model Yates $(=180.400)$ lebih besar daripada kelompok siswa yang diasuh dengan pola asuh acceptance yang mengikuti teori konseling behavioral teknik Self Management Model Cormier ( =164.200).

Hasil penelitian ini menunjukkan perhitungan diatas thitung diperoleh sebesar 2.252 dan $\mathrm{t}(28 ; 0.05)$ sebesar 6.378. Jika dibandingkan nilai thitung dengan $\mathrm{t}(\mathrm{dk} ; \alpha)$ didapatkan bahwa thitung $>\mathrm{t}(\mathrm{dk} ; \alpha)$ maka dapat disimpulkan bahwa hipotesis nol yang menyatakan "Tidak terdapat perbedaan Self autonomy antara siswa yang diasuh dengan pola asuh rejection yang mengikuti teori konseling behavioral teknik Self Management Model Yates dengan yang mengikuti teori konseling behavioral teknik Self Managament Model Cormier", ditolak. Sebaliknya, hipotesis alternatif (H1) yang menyatakan bahwa "Terdapat perbedaan Self autonomy antara siswa yang diasuh dengan pola asuh rejection yang mengikuti teori konseling behavioral teknik Self Managament Model Yates dengan yang mengikuti teori konseling behavioral teknik Self Managament Model Cormier", diterima.

Simpulan yang dapat ditarik kesimpulan menyatakan bahwa terdapat perbedaan Self autonomy antara siswa yang diasuh dengan pola asuh rejection yang mengikuti teori konseling behavioral teknik Self Management Model Yates dengan yang mengikuti teori konseling behavioral teknik Self Management Model Cormier. 
Secara deskriptif rata-rata Need of autonomy kelompok siswa yang diasuh dengan pola asuh rejection yang mengikuti teori konseling behavioral teknik Self Management Model Yates ( $=161.867)$ lebih besar daripada kelompok siswa yang diasuh dengan pola asuh rejection yang mengikuti teori konseling behavioral teknik Self Managament Model Cormier ( = 138.267).

Jadi dari hasil penelitian yang dilakukan di kelas X SMA Negeri 2 Singaraja bahwa terdapat perbedaan efektifitas konseling behavioral teknik Self Management Model Yates dan teknik Self Management Model Cormier terhadap Self Autonomy ditinjau dari pola asuh orang tua. Namun pengembangan lebih efektif menggunakan konseling behavioral teknik self Management Model Yates yang dilaksanakan pada siswa yang memiliki pola asuh acceptance.

\section{Kesimpulan}

Berdasarkan hasil penelitian dan pembahasan, maka dapat diuraikan simpulan peneliti, yaitu sebagai berikut. (1) Terdapat perbedaan Self autonomy antara siswa yang mengikuti teori konseling behavioral teknik Self Managament Model Yates dengan siswa yang mengikuti teori konseling behavioral teknik Self Managament Model Cormier. $(F=6.642 ; p<0.05)$, (2) Terdapat perbedaan Self autonomy siswa yang diasuh dengan pola asuh acceptance dengan siswa yang diasuh dengan pola asuh rejection. $(F=11.714 ; p<0.05)$, (3) Terdapat pengaruh interaksi antara teori konseling behavioral dan pola asuh orang tua terhadap Need of autonomy. $(\mathrm{F}=17.98 ; \mathrm{p}<0.05)$, (4) Terdapat perbedaan Need of autonomy antara siswa yang diasuh dengan pola asuh acceptance dengan siswa yang diasuh dengan pola asuh rejection setelah mengikuti teori konseling behavioral teknik modeling. ( $F=5.008 ; \alpha<2.048)$, (5) Terdapat perbedaan Need of autonomy antara siswa yang diasuh dengan pola asuh acceptance dengan siswa yang diasuh dengan pola asuh rejection setelah mengikuti teori konseling behavioral teknik penguatan positif. $(F=7.008 ; \alpha<2.048)$, (6) Terdapat perbedaan Need of autonomy antara siswa yang diasuh dengan pola asuh acceptance yang mengikuti teori konseling behavioral teknik modeling dengan siswa yang mengikuti teori konseling behavioral teknik penguatan positif. ( $F=3.861 ; \alpha 2.048)$, (7) Terdapat perbedaan Need of autonomy antara siswa yang diasuh dengan pola asuh rejection yang mengikuti teori konseling behavioral teknik modeling dengan yang mengikuti teori konseling behavioral teknik penguatan positif. $(\mathrm{F}=2.252 ; \alpha<2.048)$.

\section{Referensi}

Corey., Gerald 2003. teori dan Praktek Konseling dan Psikoterapi. Bandung : PT. Refika Aditama.

Kartadinata, Sunaryo, et al. 2008. Penataan Pendidikan Profesi Konselor dan Layanan Bimbingan dan Konseling dalam Jalur Pendidikan Formal. Jakarta : Departemen Pendidikan Nasional

Suarni,Ketut.2004. Meningkatkan Motivasi Berprestasi Sekolah Menengah Umum di Bali dengan Strategi Pengelolaan Diri Model Yates (Studi Kuasi Eksperimental Pada Siswa Kelas 1 SMU di Bali).Disertasi (tidak diterbitkan).Yogyakarta. Universitas Gajah Mada.

Sukardi.2003. Metodelogi Penelitian Pendidikan. Jakarta : PT. Bumi Aksara

Undang-undang Sistem Pendidikan Nasional Pasal 1 Ayat 1 Tahun 2003

Yates, BT.1985. Self Management : The Science and The Art Of Helping Yourself. California: Ward Sworth Publishing.Co 
The authors declare that they have no significant competing financial, professional or personal interests that might have influenced the performance or presentation of the work

Copyrights Holder: <authors $><$ year $>$

https://doi.org/10.xxxx/xxxxx

Open Access Article | CC-BY Creative Commons Attribution 4.0 International License.

Word Count: described in this manuscript.

First Publication Right: BISMA The Journal of Counseling

@creative 